\title{
Mustasotilaskärpäsen (Hermetia illucens) kasvatus Keski-Suomen olo- suhteissa ja hyödyntäminen biomassojen käsittelyssä
}

\author{
Sami Virtanen ${ }^{1)}$, Tiina Siimekselä ${ }^{1)}$, Tuure Parviainen ${ }^{2)}$, Matti Tähtinen ${ }^{2)}$ \\ ${ }^{1)}$ Jyväskylän ammattikorkeakoulu Biotalousinstituutti, Tuumalantie 17, 43130 Tarvaala, etunimi.suku- \\ nimi@jamk.fi \\ 2)Teknologian tutkimuskeskus VTT Oy, etunimi.sukunimi@vtt.fi, PL 1000,02044 VTT
}

\section{TIIVISTELMÄ}

Jyväskylän ammattikorkeakoulun Biotalouskampuksella toteutettiin hyönteiskasvatuksen demonstraatioympäristö VinsectS - Hyönteistalous osana Viitasaari-Saarijärvi seutukunnan kiertotaloutta -hankkeessa keväällä 2018. Hankkeessa tutkittiin mustasotilaskärpäsen (Hermetia illucens) ympärivuotisia kasvatusmahdollisuuksia Keski-Suomen olosuhteissa sekä toukkien kykyä hyödyntää erilaisia biomassasivuvirtoja ravinnokseen.

Mustasotilaskärpänen on tropiikin hajottaja, jolla on nopea elinkierto ja tehokas biomassan hyödynnyskyky. Optimissa kasvatusolosuhteissa sen elinkierto on 35-42 päivää, joista 14-24 päivää se viettää biomassaa prosessoivana toukkana. Toukka syö kaksi kertaa loppupainonsa verran ja konvertoi biomassasta 50-80 \% toukkamassaksi. Mustasotilaskärpänen ei ole tautivektori ja toukkien biomassan prosessoinnin on havaittu vähentävän bakteerimassaa ja nopeuttavan lääkeaineiden hajoamista sekä vähentävän kasvihuonekaasupäästöjä.

Hyönteiskasvattamo rakennettiin 6 metrin ISO-konttiin, johon asennettiin olosuhdehallintalaitteisto, etävalvonta ja kasvatusrullakot. Kontti eristettiin ympärivuotista kasvatusta varten. Kasvattamossa käytetään IoT-tekniikkaa automatisoidussa olosuhdehallinnassa. Hankkeen aikana ympärivuotisen hyönteiskasvatuksen havaittiin olevan mahdollista olosuhteiden pysyessä tavoitearvoissa niin kesällä kuin talvellakin. Kasvattamon lämpötila pysyi tasaisena, ilmankosteuteen ulkoiset tekijät kuitenkin vaikuttivat. Ilmankosteudella onkin suuri rooli hyönteisten elinkierron optimointiin. Hankkeen mittakaavassa hyönteiskasvatus ei tuottanut haitallisia määriä kaasuja, vaan kasvattamon hiilidioksidi- ja ammoniakkipitoisuudet pysyivät sisätyöympäristön viitearvoissa.

Mustasotilaskärpäsillä suoritettiin ruokintakokeita erilaisten biomassojen rehuarvojen määrittämiseksi. Biomassat kattoivat sivuvirtoja catering-jakeista siipikarjan lantaan. Biomassojen verrokkina käytettiin teollista siipikarjan rehua. Ruokintakokeet toteutettiin punnitsemalla 100 toukan alku- ja loppupaino ja jäljelle jääneen biomassan jäännöspaino ja kuiva-aineosuus toukkien syönnin määrittämiseksi. Lisäksi tarkkailtiin toukkien kuolleisuutta. Tuloksista voidaan päätellä usean biomassan olevan vähintään yhtä hyvää, ellei parempaa rehua mustasotilaskärpäsille kuin siipikarjan rehun. Esiin nousivat hiilihydraattipitoiset elintarvikepohjaiset biomassat kuten catering- ja leipomojakeet. Korkean (yli 20\%) rasvapitoisuuden biomassat ja vaikeasti prosessoitavat kuidut, kuten ligniini, puolestaan soveltuvat heikommin mustasotilaskärpäsen rehuiksi.

VinsectS-hankkeessa kartoitettiin seutukunnan hyönteistalouteen soveltuvien sivuvirtojen ja biomassojen lähteitä sekä hyönteiskasvatukseen soveltuvia ja kiinnostuneita yrityksiä ja yrittäjiä. Tulosten pohjalta hankkeessa luotiin hyönteistalouden tiekartta ja arvoketju Viitasaari-Saarijärven seutukunnalle. Mm. Euroopan aluekehitysrahaston (EAKR) rahoittama ja VTT:n hallinnoima hanke toteutettiin 5.2.2018-30.11.2019.

Asiasanat: mustasotilaskärpänen, hyönteistalous, kiertotalous, biomassojen käsittely 


\section{Johdanto}

Hyönteisten käyttö erilaisten biomassojen ja orgaanisten jätteiden käsittelyyn on yksi kiinnostavimmista hyönteisalan sovelluksista tällä hetkellä. Hyönteisten avulla voidaan käsitellä kustannustehokkaasti ja turvallisesti myös yleensä vaikeasti käsiteltäviä jätteitä ja sivuvirtoja, kuten lietteitä, elintarviketeollisuuden sivuvirtoja ja biojätteitä. Esimerkiksi mustasotilaskärpäsen (Hermetia illucens) toukkien avulla lantaa, lietteitä ja muita biojätteitä pystytään käsittelemään tehokkaasti ja nopeasti korkeampiarvoisiksi biomassoiksi. Toukat ilmastavat biomassan ja poistavat siitä nesteen lähes kokonaan. Toukkakäsittely vähentää biojätteen käsittelyn hajuhaittoja, lisäksi toukat vähentävät ja poistavat jätteestä haitallisia bakteereja (mm. Escherichi coli, Salmonella ja Campylobacter jejuni). Toukat eivät itse saastu eivätkä levitä bakteereja ympäristöön. (Lalander ym. 2014, Heiska ja Huikuri 2017).

Hyönteislajiksi tähän tutkimukseen valittiin mustasotilaskärpänen (Hermetia illucens) lajin ominaisuuksien perusteella. Se on trooppinen hajottaja, jolla on laaja ruokavalio, nopea elinkierto ja tehokas biomassan hyödynnyskyky. Se on kestävä erilaisille olosuhteille ja tekijöille. Laji on kotoisin neotrooppiselta alueelta, mutta on nykyisin levinnyt kaikille trooppisille ja subtrooppisille vyöhykkeille kaikilla mantereilla. Elinalue rajautuu Alpeille, joten sitä ei vielä esiinny Suomessa.

Mustasotilaskärpänen käy lävitse täydellisen muodonmuutoksen. Optimiolosuhteissa sen elinkierto on 6-8 viikkoa. Mustasotilaskärpäsen munat ovat kermanvärisiä tai kellertäviä ja naaras munii noin 500 munaa rykelmään. Kärpänen kasvaa 2-3 cm pituiseksi sekä toukkana että aikuisena. Esikoteloitunut toukka painaa noin neljännesgramman. Aikuisena mustasotilaskärpänen ei enää syö mitään, vaan parittelee ja munii vararavintonsa varassa. Mustasotilaskärpäsen toukat sisältävät ravintoarvoiltaan noin $45 \%$ proteiinia, $35-45 \%$ rasvaa sekä kitiiniä ja hivenaineita. Toukkamassa voidaan jalostaa lemmikkien ja tuotantoeläinten rehuiksi, rasva- ja öljyjakeiksi, biodieselin raaka-aineeksi, kitosaaniksi (Wang 2017). Lisäksi toukkien ulosteen ja biomassajäännöksen seosta, frassia, voidaan käyttää lannoitteena (Green ja Popa 2012).

\section{Materiaalit ja menetelmät}

Hyönteiskasvattamo rakennettiin 6 metrin ISO-konttiin. Rahtikontin seinät eristettiin ja sisätilat päällystettiin vesivanerilla. Kasvattamo jaettiin kolmeen osaan; toimistotilaan, toukkapuoleen ja aikuispuoleen. Kasvattamon lämmittämiseksi asennettiin yksi sähköpatteri kummallekin hyönteispuolelle. Kasvattamon ilmanvaihto toteutettiin passiivisilla tuloilmaventtiileillä kasvattamon yläosassa ja aktiivisilla poistoilmapuhaltimilla kasvattamon alaosassa. Lisäksi kasvattamon olosuhteita tasattiin sisätilojen seinätuulettimilla. Ilmankosteutus toteutettiin alkuun ultraäänisumuttimilla, jotka vaihdettiin tehokkaampaan vesipumppuun ja suurempiin suuttimiin ultraäänisumuttimien menettäessä tehoaan ja tukkeutuessa.

Mustasotilaskärpäset parittelevat aktiivisimmin aamuauringon kajoa vastaavilla aallonpituuksilla, minkä vuoksi aikuisten kärpästen parittelua varten kasvattamoon asennettiin suurpainenatriumlamppu. Kasvattamon valaistusrytmi säädettiin käänteiselle kahdentoista (12) tunnin vuorokausirytmille eli kasvattamon valot olivat päällä yöllä ja pois päältä päivisin. Tämä tasasi kasvattamon lämpötiloja ja lisäsi työskentelymukavuutta.

Hyönteiskasvattamon olosuhteita hallittiin automaattisesti mitatun datan perusteella. Kasvattamoon asennettiin 20 kappaletta RuuviTag-sensoreita, jotka mittasivat kasvattamon lämpötilaa ja ilmankosteutta. Lisäksi kasvattamossa oli myös kaasuanalysaattori, joka mittasi hiilidioksidi- ja ammoniakkipitoisuuksia. Mitattu data kerättiin palvelimelle ja lähetettiin Grafana-serverille, josta sitä luettiin pythonpohjaisella ohjelmalla, joka sääti olosuhdelaitteiston toimintaa asetettujen arvojen sisällä. Optimaalisten olosuhteiden määritelmänä käytettiin kirjallisuusarvoja lämpötila $27-30{ }^{\circ} \mathrm{C}$ ja ilmankosteus $50-60 \%$ (Park 2015). 
Ruokintakokeissa tutkittiin erilaisten biomassojen ja maatalouden sivuvirtojen soveltuvuutta mustasotilaskärpäsen rehuksi. Biomassat kerättiin seutukunnan toimijoilta. Näytteistä määritettiin kuiva-ainepitoisuus punnitsemalla näytettä 300 grammaa foliovuokaan ja kuumentamalla sitä 24 tuntia $105^{\circ} \mathrm{C}$ (Mattila ym. 2001). Kuiva-ainemäärityksistä suoritettiin kaksi rinnakkaista määritystä näytettä kohti. Näytteet tasattiin kuiva-aineen suhteen keskenään alhaisimpaan kuiva-ainepitoisuuteen näytteiden kuivaamisen tarpeen poistamiseksi varsinaisissa ruokintakokeissa.

Ruokintakokeet suoritettiin neljässä erässä, joissa kolmessa oli erilainen näytevalikoima ja yksi oli aiemman ruokintakokeen uusinta. Kaikissa ruokintakoe-erissä näytteistä suoritettiin neljä rinnakkaista otosta ja verrokkina toimi teollinen kananrehu. Ruokintakokeet suoritettiin yhden litran pakasterasioissa (mitat: halkaisija $11.5 \mathrm{~cm}$, leveys $8.15 \mathrm{~cm}$, korkeus $11 \mathrm{~cm}$ ja tilavuus 1 litra). Rasian kanteen leikattiin aukko, joka päällystettiin verkolla. Rasiat ja kannet numeroitiin ja punnittiin. Rasioihin siirrettiin 100 kappaletta viiden päivän ikäistä mustasotilaskärpäsen toukkaa (5-dol) ja niiden lähtöpaino punnittiin. Rasioihin lisättiin punnittu määrä tutkittavaa rehuseosta kolmesti viikossa kahden viikon ajan. Jos toukat eivät näyttäneet vielä koteloitumisen merkkejä, lisättiin rasioihin kolmannella viikolla rehun sijaan $10 \mathrm{ml}$ vettä. Ensimmäisten koteloiden ilmestyessä toukat eroteltiin rehujäännöksestä. Toukat laskettiin ja punnittiin, samoin jäljellä ollut rehumassa. Toukat teurastettiin pakastamalla. Toukka- ja rehujäännöksestä määritettiin kuiva-aine ja tuloksista laskettiin rehun kuiva-aine reduktio ja toukkien rehun muuntosuhde (FCR) ja biomassan muuntosuhde (BCR).

\section{Tulokset}

Hyönteiskasvattamon lämpötila pysyi tavoitearvojen välissä koko tarkkailujakson ajan (Kuva 1). U1koiset olosuhteet eivät vaikuttaneet kasvattamon lämpötiloihin huomattavasti, poikkeuksena kesän helteet, jolloin auringonpaiste varautui kasvattamon seiniin ja sitä kautta eristeisiin nostaen lämpötilaa.

Hyönteiskasvattamon ilmankosteuden tavoitearvojen saavuttaminen osoittautui haasteellisemmaksi kuin lämpötilan (Kuva 2). Ensimmäinen kostutinjärjestelmä osoittautui riittämättömäksi ja se korvattiin tehokkaammalla järjestelmällä. Myös ulkoiset olosuhteet vaikuttivat kasvattamon ilmankosteuteen. Kuivempi ulkoilma alensi kasvattamon ilmankosteutta ilmanvaihdon kautta. Tarkkailujakson aikana ilmankosteuden tavoitearvoja ei saavutettu ja siksi uusi järjestelmä otettiin käyttöön.

Hyönteiskasvattamon ilmanlaatu pysyi hyvänä tarkkailujakson aikana. Biomassan hajoamisprosessi ja toukkien aineenvaihdunta ei vapauttanut datan perusteella huomattavia määriä hiilidioksidia kasvattamon ilmaan. Mittausdatan perusteella suurin yksittäinen hiilidioksidin lähde oli ihminen; kasvattajan saapuminen ja poistuminen kasvattamosta oli selvästi havaittavissa hiilidioksidimittauksen datassa. Kuvassa 3 nähtävät hiilidioksidipiikit ajoittuvat hyönteiskasvattamon esittelytilaisuuksiin, jolloin kasvattamossa oli läsnä useita ihmisiä. Hyönteiskasvattamon sisäilman ammoniakkipitoisuudet pysyivät pääsääntöisesti nollassa tarkkailujaksolla. Ammoniakkipitoisuudet nousivat mitattaviksi ja aistinvaraisesti huomattaviksi toukkavaiheiden lopussa, jolloin valkuaispitoisen rehun typpi vapautui ammoniakkina ilmaan (Kuva 4).

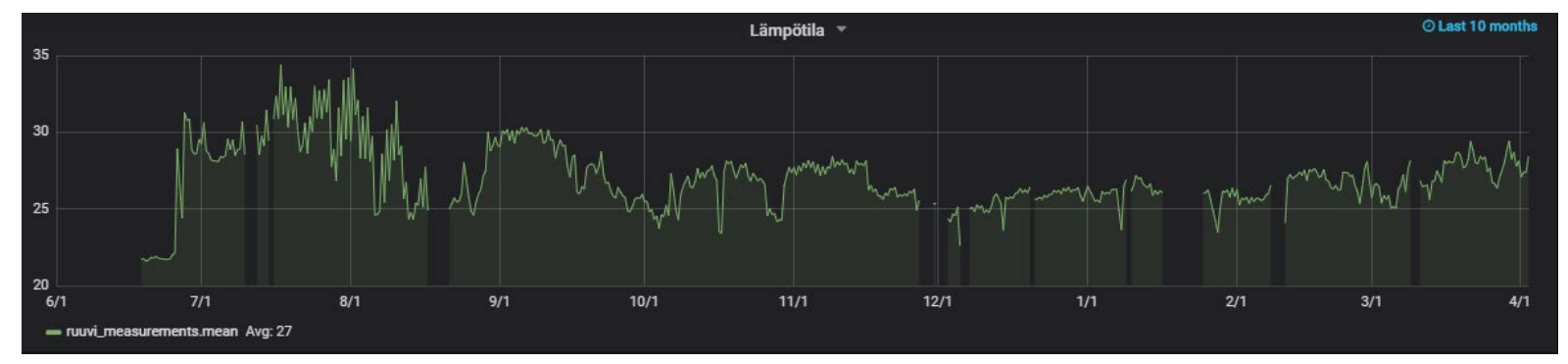

Kuva 1. Hyönteiskasvattamon keskilämpötila 10 kuukauden ajalta 6/2018-4/2019 


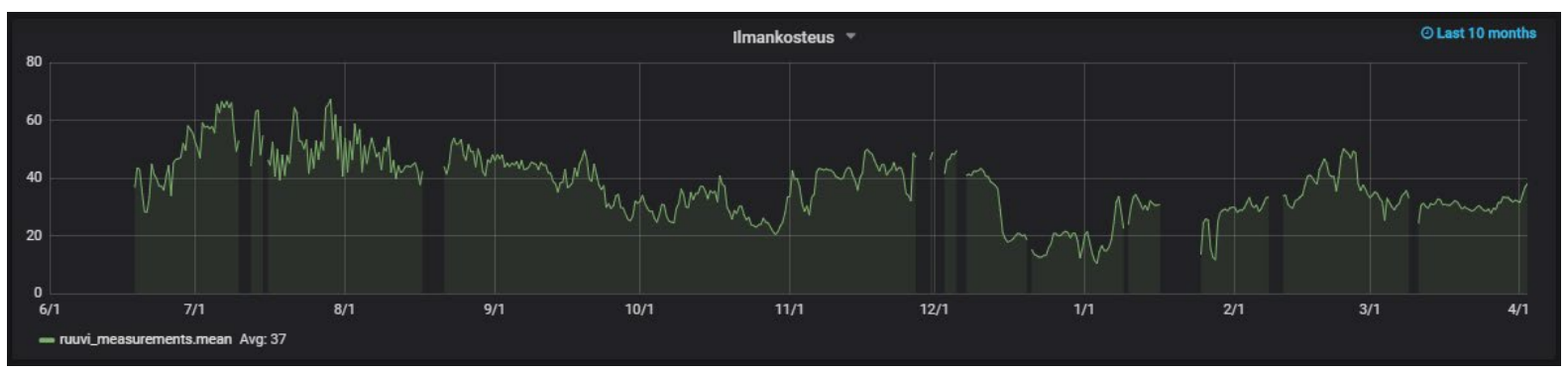

Kuva 2. Hyönteiskasvattamon keski-ilmankosteus 10 kuukauden ajalta 6/2018-4/2019

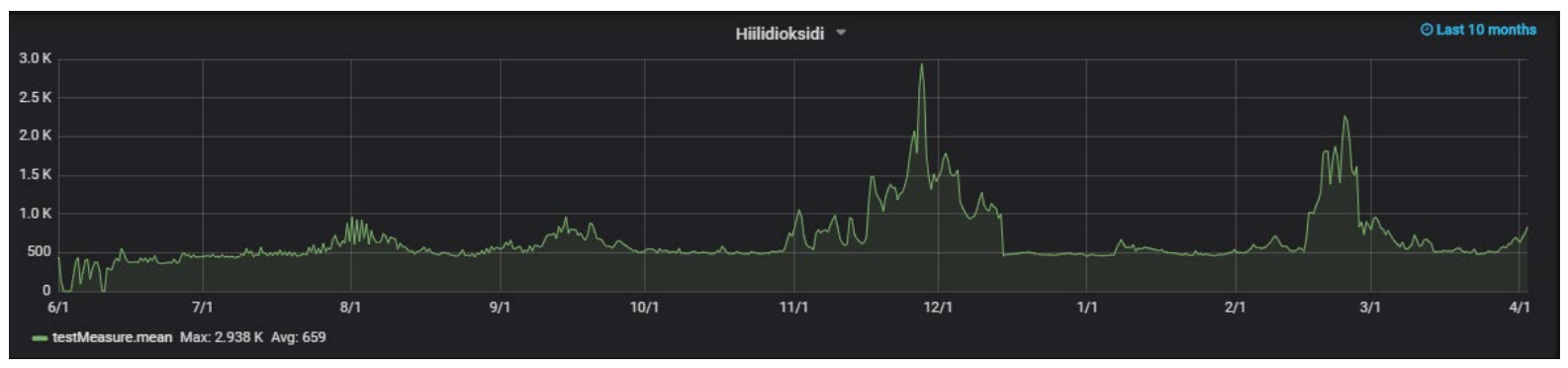

Kuva 3. Hyönteiskasvattamon CO2-pitoisuus 10 kuukauden ajalta 6/2018-4/2019

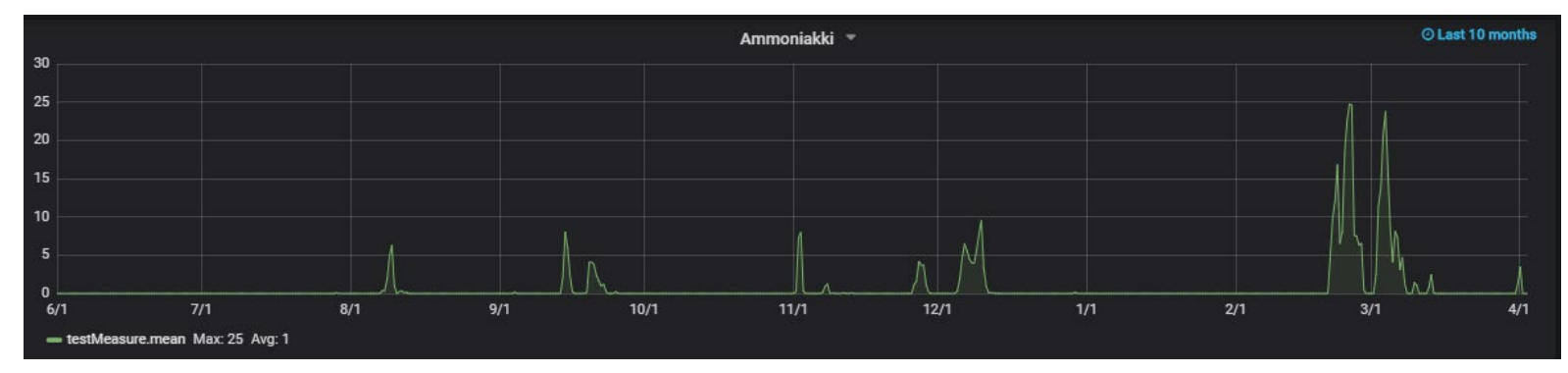

Kuva 4. Hyönteiskasvattamon NH3-pitoisuus 10 kuukauden tarkkailujaksolla 6/2018-4/2019

Kosteuden vaikutus kasvuun

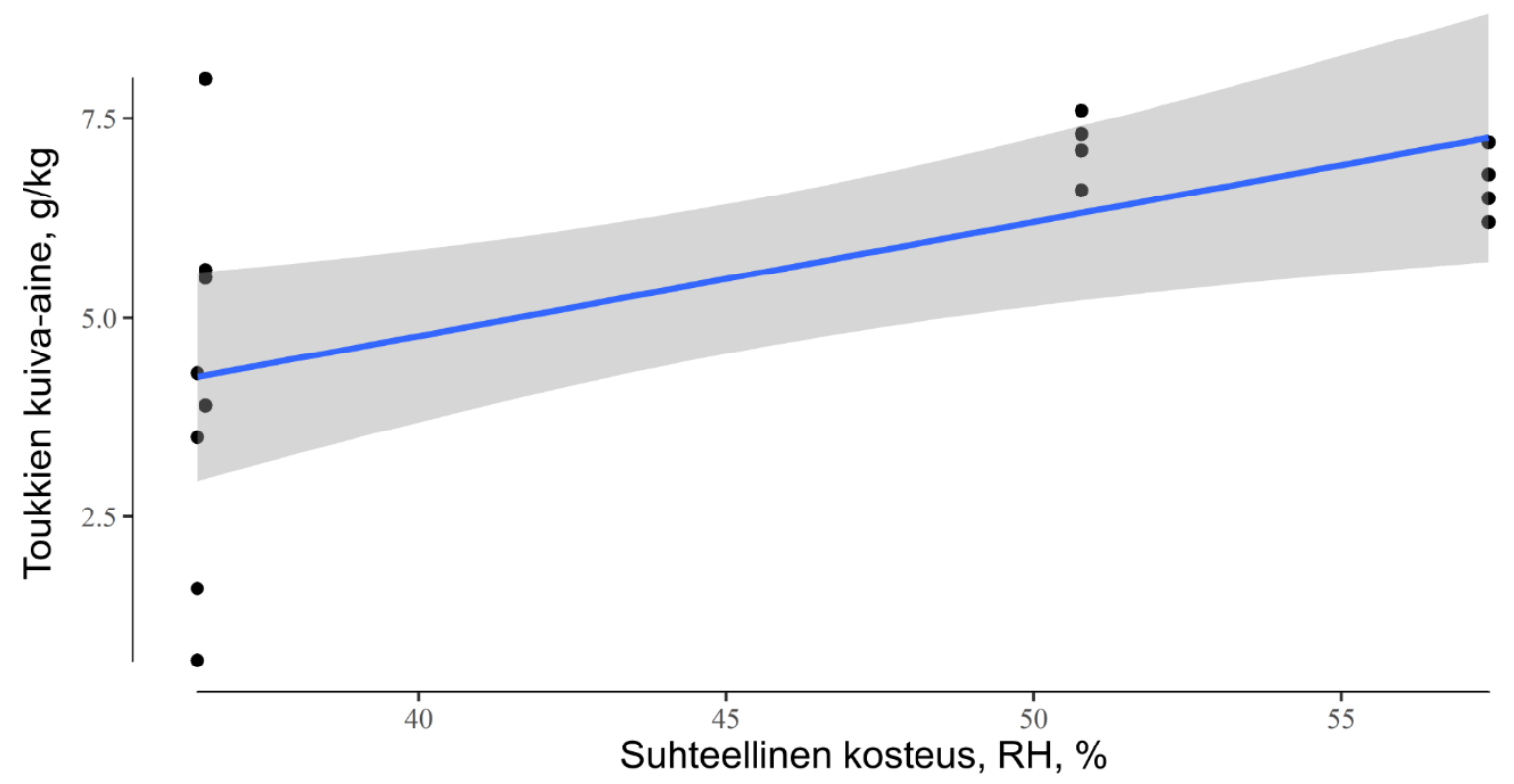

Kuva 5. Toukkien kasvu eri kosteusolosuhteissa kananrehulla 
Mustasotilaskärpästoukkien kasvulle kosteus osoittautui tärkeäksi tekijäksi (Kuva 5). Käytännössä kosteus osoittautui selittäväksi tekijäksi kasvatustuloksille. Toukkien kuivapainolla ja kasvatustilan suhteellisella kosteudella on lineaarinen riippuvuussuhde ja harmaalla on esitetty tilastollinen $95 \%$ ennustejakauma harmaalla värillä. Kasvatuskosteuden noustessa yli 50 RH\% suhteellisen kosteuden voidaan kasvatustuloksia pitää vertailukelpoisina. Matalassa kosteudessa toukkien syömä biomassan määrä vähenee ja kuolleisuus kasvaa. Matalassa kosteudessa tuloksien keskihajonta kasvaa ja silloin pienet poikkeamat kasvatusympäristössä vaikuttavat tuloksiin merkittävästi alentaen toukkien muuntosuhdetta.

Alhaisemmassa kosteudessa tehdyt ruokintakokeet kuitenkin antavat ensivaikutelman eri rehujen soveltuvuudesta. Useimmat testatuista biomassoista soveltuivat mustasotilaskärpästen ruokintaan (Taulukko 1). Kalan teurasjätteillä tehdyt kokeet kuitenkin johtivat koe-erien keskeytymisiin toukkien kuoltua ja siten niiden tulokset ovat jätetty pois. Tämä voi johtua toukkien hengityksen estymisestä, jos rasvat peittävät hengitystiet ja estävät hapen saannin. Kuiva-aineen reduktio kuvaa kuinka paljon rehun kuiva-aineesta toukat söivät. Rehun muuntosuhde kuvaa kuinka paljon toukka tarvitsee rehua kasvaakseen, pienempi arvo kuvaa parempaa suhdetta. Biomassan muuntosuhde kuvaa kuinka paljon rehun kuiva-aineesta muuttui toukkamassaksi, suurempi arvo kuvaa parempaa suhdetta.

Taulukko 1. Ruokintakokeiden tulokset. Luvut rinnakkaisten koe-erien keskiarvoja.

\begin{tabular}{|c|c|c|c|c|c|c|c|c|c|c|}
\hline Biomassa & Leipä & $\begin{array}{l}\text { Ruoka- } \\
\text { jae }\end{array}$ & Ohra & Biojäte & $\begin{array}{l}\text { Kala- } \\
\text { leipä- } \\
\text { seos }\end{array}$ & $\begin{array}{l}\text { Peru- } \\
\text { nan- } \\
\text { kuori }\end{array}$ & $\begin{array}{l}\text { Kanan- } \\
\text { lanta }\end{array}$ & $\begin{array}{l}\text { Leipä- } \\
\text { hyö- } \\
\text { henseos }\end{array}$ & $\begin{array}{l}\text { Kanan- } \\
\text { rehu1 }\end{array}$ & $\begin{array}{l}\text { Kanan- } \\
\text { rehu2 }\end{array}$ \\
\hline Annettu rehu, g & 285.88 & 203.99 & 181.32 & 181.27 & 181.32 & 236.65 & 228.08 & 202.78 & 169.25 & 181.35 \\
\hline $\begin{array}{l}\text { Rehun kuiva- } \\
\text { aine, g }\end{array}$ & 60.04 & 42.84 & 48.96 & 48.94 & 48.96 & 34.79 & 69.80 & 29.81 & 24.88 & 48.96 \\
\hline Rehujäännös, g & 56.98 & 81.47 & 16.99 & 22.51 & 23.92 & 57.95 & 69.80 & 36.71 & 8.25 & 29.55 \\
\hline $\begin{array}{l}\text { Rehujäännöksen } \\
\text { kuiva-aine, g }\end{array}$ & - & - & 13.65 & 19.75 & 19.65 & 20.43 & 22.23 & 9.80 & 8.25 & 21.13 \\
\hline $\begin{array}{l}\text { Kuiva-aine } \\
\text { reduktio, \% }\end{array}$ & - & - & $72.1 \%$ & $59.6 \%$ & $59.9 \%$ & $41.3 \%$ & $68.2 \%$ & $67.1 \%$ & $66.8 \%$ & $56.8 \%$ \\
\hline $\begin{array}{l}100 \mathrm{kpl} \text { toukkien } \\
\text { lähtöpaino, } \mathrm{g}\end{array}$ & 0.95 & 0.81 & 0.81 & 0.59 & 0.52 & 0.6 & 0.61 & 0.66 & 0.60 & 0.38 \\
\hline $\begin{array}{l}100 \mathrm{kpl} \text { toukkien } \\
\text { loppupaino, } \mathrm{g}\end{array}$ & 21.32 & 20.92 & 17.27 & 16.23 & 6.94 & 13.96 & 10.66 & 16.33 & 19.14 & 18.6 \\
\hline $\begin{array}{l}100 \mathrm{kpl} \text { toukkien } \\
\text { kuivapaino, } \mathrm{g}\end{array}$ & 7.68 & 7.3 & 6 & 6.08 & 4.2 & 4.22 & 2.53 & 5.77 & 7.24 & 7.15 \\
\hline $\begin{array}{l}100 \mathrm{kpl} \text { toukkien } \\
\text { kuiva-aine, } \%\end{array}$ & $35.3 \%$ & $36.9 \%$ & $34.8 \%$ & $37.4 \%$ & $61.4 \%$ & $27.4 \%$ & $22.9 \%$ & $32.2 \%$ & $34.9 \%$ & $38.5 \%$ \\
\hline Kuolleisuus, kpl & 27.75 & 15 & 12.5 & -1.5 & 16.75 & 9.25 & 4.25 & 8.5 & 7.75 & 2.25 \\
\hline Kasvuaika, vrk & 18 & 11 & 20 & 20 & 20 & 22 & 22 & 15 & 13 & 20 \\
\hline $\begin{array}{l}\text { Rehun muunto- } \\
\text { suhde, FCR }\end{array}$ & 10.74 & 5.86 & 9.51 & 9.78 & 22.70 & 12.80 & 14.85 & 10.17 & 8.41 & 8.16 \\
\hline $\begin{array}{l}\text { Biomassan } \\
\text { muuntosuhde, } \\
\text { BCR }\end{array}$ & $9.3 \%$ & $17.1 \%$ & $10.5 \%$ & $10.2 \%$ & $4.4 \%$ & $7.8 \%$ & $6.7 \%$ & $9.8 \%$ & $11.9 \%$ & $12.3 \%$ \\
\hline
\end{tabular}




\section{Tulosten tarkastelu}

Tämän tutkimuksen tulosten perusteella mustasotilaskärpästen kasvatus onnistuu Suomen olosuhteissa ympärivuotisesti ulkotiloissa eristettyä konttia käyttäen. Lämpötilan suhteen ongelmia ei tuottanut talven pakkaskelit, vaan kesän helteet, jolloin eristeet varasivat liikaakin lämpöä. Kesäkaudella hyönteiskasvattamon sisäiset lämpötilat olivat tasaisia, mutta talvikaudella erottui kerrostumista ylempien kerroksien ollessa lämpimämpiä kuin lattian. Tämä johti kosteuden tiivistymiseen lattialle sekä hidasti alemmissa kerroksissa olevien hyönteisten toimintaa. Syynä tähän oli hyönteiskasvattamon lattian puutteellinen eristys, minkä vuoksi lämpö karkasi kontin metallirakenteisiin ja sitä kautta maahan.

Lämpötilaa tärkeämpi olosuhdetekijä oli ilmankosteus. Erityisesti muninnan onnistumisen ja toukkien kuoriutumisen varmistumiseksi hyönteiskasvattamon ilmankosteuden tulisi olla optimiarvoissa (Holmes ym. 2012). 5-dol ja sitä vanhemmat toukat saavat tarvitsemansa kosteuden rehusta ja aikuiset kärpäset eivät tarvitse kosteutta erikseen. Sen sijaan munat ovat erityisen herkkiä kuivumiselle ja olosuhteiden muutoksille, samoin naaraat eivät suostu munimaan epäotollisissa olosuhteissa. Koejaksojen aikana ilmeni useita ongelmia ilmankosteuden ylläpidossa ja se näkyi ongelmina niin populaation ylläpidossa kuin ruokintakokeissa. Pienessä kokoluokassa suoritetut ruokintakokeet olivat herkkiä kuivumiselle, mikä lisäsi toukkien kuolleisuutta ja vääristi tuloksia.

Hyönteiskasvattamon sisäilma pysyi normaalina koejaksojen aikana. Kasvattamon hiilidioksidipitoisuus pysyi keskimäärin hyvän sisäilmaluokituksen rajoissa $\left(\mathrm{CO}_{2}\right.$ alle $\left.700 \mathrm{ppm}\right)$. Kasvattamon ammoniakkipitoisuus pysyi keskimäärin nollassa, mutta teollisella kananrehulla ruokittaessa ammoniakkipitoisuudet nousivat toukkavaiheen lopussa jäljellä olleen rehun valkuaisen hajotessa typpiyhdisteiksi. Toukkavaiheen lopussa toukat valmistautuvat koteloitumaan lopettaen syömisen ja vähentäen aktiivisuuttaan, jolloin rehujäännös jää prosessoimatta ja hajoaa. Näitä päästöjä voidaan minimoida optimoimalla toukkien ruokintaa siten, ettei rehua jää ylitse, tai käyttämällä vähemmän valkuaista sisältäviä rehuja, kuten ruokasivuvirtoja. Yleinen mielipide kasvattajien kesken oli kuitenkin, että siirtyminen ruokasivuvirtojen käyttöön rehuna paransi hyönteiskasvattamon ilmanlaatua ja työskentelyviihtyvyyttä.

Ruokintakokeissa paras tulos saatiin catering-pohjaisella ruokajätteellä. Sillä saavutettiin verrokkia nopeampi kasvuaika, suurempia toukkia sekä parempi rehun ja biomassan muuntosuhde. Myös hiilihydraattipitoisilla biomassoilla kuten leipäjakeella ja jauhetulla ohralla saatiin verrokin tasoisia tuloksia. Sivuvirroista biojätteellä saadut tulokset olivat myös rehun ja biomassan muuntosuhteen lupaavia, mutta kasvuaika oli verrokkia pitempi. Korkea rasvapitoisuus ja vaikeasti prosessoitavat kuidut, kuten ligniinipohjaiset jakeet, eivät sopineet mustasotilaskärpäsen ruokintaan. Liiallinen rasva johti toukkien tukehtumiseen ja kasvattamon ilmanlaadun heikkenemiseen. Ruokintakokeiden tuloksia tarkastellessa on kuitenkin huomioitava olosuhteiden vaikutukset. Ruokintakokeiden aikana hyönteiskasvattamossa ei saavutettu optimiolosuhteita. Alhainen ilmankosteus johti testattujen rehujen kuivumiseen, joka vaikutti toukkien kuolleisuuteen, kykyyn prosessoida rehua ja aktiivisuuteen. Tuloksia tulisi tarkastella enemmän suuntaa-antavina kuin luotettavina. Nämä muuntosuhteet ovat kuitenkin lähinnä kosteuden takia alhaisempia. Tulokset ovat kuitenkin saman suuntaisia muiden tutkimuksien kanssa. Cecilia Lalanderin samankaltaisessa koeasetelmassa esiin nousivat elintarvikepohjaiset biomassat mustasotilaskärpästen rehuina, vaikka heidän tuloksien pohjalta muuntosuhteet ovat korkeampia kuin tässä kokeessa esitetyt tulokset (Lalander ym. 2018).

\section{Johtopäätökset}

Mustasotilaskärpäskasvattamoa suunnitellessa tulee varmistaa optimaalisen ilmankosteuden saavuttaminen. Ympärivuotinen kasvatus onnistuu eristyksen avulla, konttimallisessa kasvattamossa tulee eristää kaikki pinnat tasaisesti olosuhteiden kerrostumisen estämiseksi. Mustasotilaskärpästen kasvatus ei 
tuota huomattavia ilmanlaatuun vaikuttavia kaasuja, mutta ilmanlaadun mittausta ja tarkkailua on hyvä suorittaa siirtyessä suurempiin kokoluokkiin.

Mustasotilaskärpäsen ruokintaan sopivat erilaiset biomassat ja etenkin catering-pohjaisilla jakeilla on mahdollista saada teollista rehua parempi kasvu. Huomioiden teollisen rehun ammoniakkipäästöt, ovat ruokavirrat parempaa rehua kärpäsille myös kasvattajan näkökulmasta. Biojätteellä saadut tulokset osoittavat jätteidenkäsittelyn mustasotilaskärpäsillä olevan mahdollista kasvatuksellisesta näkökulmasta. Ruokintakokeissa ei kuitenkaan seurattu toukkien kehitystä aikuisiksi ja seuraavien sukupolvien kasvua, joten eri biomassojen pitempiaikaisia vaikutuksia ei näillä tuloksilla voi arvioida.

\section{Kiitokset}

VinsectS-hanketta rahoittivat Keski-Suomen liitto/Euroopan aluekehitysrahasto (EAKR), Sammakkokangas Oy sekä Viitasaari-Saarijärvi seutukunta.

\section{Kirjallisuus}

Green, T.R., \& Popa, R. 2012. Enhanced ammonia content in compost leachate processed by black soldier fly larvae. Applied biochemistry and biotechnology, 166: 1381-1387. https://doi.org/10.1007/s12010-011-9530-6

Heiska, S. \& Huikuri, N. 2017. Hyönteistuotannon esiselvitys. Luonnonvara- ja biotalouden tutkimus 76/2017. Helsinki. 146 s.

Holmes, L.A. Vanhaerhoven, S.L. \& Tomberlin, J.K. 2012. Relative humidity effects on the life history of Hermetia illucens (Diptera: Stratiomyiade). Entymology Society of America. Environmental Entomology 41:971978. https://doi.org/10.1603/EN12054

Lalander, C. Diener, S. Zurbürgg, C. \& Vinnerås, B. 2018. Effects of feedstock on larval development and process efficiency in waste treatment with black soldier fly (Hermetia illucens). Journal of Cleaner Production 208. https://doi.org/10.1016/j.jclepro.2018.10.017

Lalander, C., Fidjeland, J., Diener, S., Eriksson, S. \& Vinnerås, B. 2014. High waste-to-biomass conversion and efficient Salmonella spp. reduction using black soldier fly for waste recycling. Agronomy for Sustainable Development 35: 261-271.https://doi.org/10.1007/s13593-014-0235-4

Mattila, P., Piironen, V. \& Ollilainen, V. 2001. Elintarvikekemia ja -analytiikka. Yliopistopaino. Helsinki.

Park, H.H. 2015. The Black Soldier Fly Larvae Manual. Massachusetts Amherstin yliopisto. https://scholarworks.umass.edu/cgi/viewcontent.cgi?article=1015\&context=sustainableumass_studentshowcase.

Wang, Y.S. \& Shelomi, M. 2017. Review of black soldier fly (Hermetia illucens) as animal feed and human food. Foods 6: 91. https://doi.org/10.3390/foods6100091 